\title{
ACUTE AND SUBCHRONIC ORAL TOXICITIES OF “DA DAY AN CHAU" TABLETS IN EXPERIMENTAL ANIMALS
} Tran Thanh Tung, Dao Viet Hoang, Pham Thi Van Anh and Dang Thi Thu Hien Hanoi Medical University

In this study, the toxicities of "Da day An Chau" tablets (DDAC) were assessed on experimental animals. To evaluate the acute toxicity on Swiss mice according to World Health Organization Guidance and to determine $L D_{50}$ refer to the method of Litchfield - Wilcoxon. The subchronic toxicity study of DDAC at two doses $(0.58 \mathrm{~g} / \mathrm{kg} /$ day and $1.74 \mathrm{~g} / \mathrm{kg} /$ day) was conducted in rats for four consecutive weeks. Evaluation of general conditions and weight of rats during the study period. Rat's blood was taken for hematological and biochemical evaluations. The livers and kidneys microscopes were evaluated at the end of the experiment. The result revealed that mice were taken up to a maximum dose of $25.71 \mathrm{~g} / \mathrm{kg}$ with no symptoms of acute toxicity; $L D_{50}$ of DDAC has not been determined. At two doses, the subchronic toxicity study did not change rats' body weight, hematological, biochemical parameters, and microscopic of the livers and kidneys during the study period.

Keywords: Acute toxicity, subchronic toxicity, Da day An Chau, experimental animals

\section{INTRODUCTION}

Gastroesophageal reflux disease (GERD) is a common disease previously found in European and American countries. In recent years, the report of Asia - Pacific gastrointestinal conferences, the disease has been increasing rapidly in Asia. ${ }^{1}$ GERD causes discomfort to patients and has the risk of causing serious complications such as ulcers, stenosis, esophageal bleeding, even cancer. ${ }^{2}$ A system of 19 studies suggests that GERD causes an increase in time off from work, decreased productivity, reduced physical activities, reduced sleep quality, and overall quality of life. ${ }^{3}$ Since gastric acid plays a key vital role in the pathogenesis of reflux esophagitis, luminal $\mathrm{pH}$ control is considered necessary in managing this disease. Anti - secretory drugs, such as histamine $\mathrm{H} 2$ receptor antagonists

Corresponding author: Dang Thi Thu Hien,

Hanoi Medical University

Email: thuhien2629@gmail.com

Received: 01/12/2020

Accepted: 08/03/2021 and proton pump inhibitors, they have been determined to be very effective against acid reflux esophagitis in humans and animals. ${ }^{4}$ In Vietnam, there are many traditional medicines used to treat and improve clinical symptoms of GERD. ${ }^{5}$

The DDAC comprises medicinal materials available in Vietnam, used as a folk medicine to treat GERD. There have been many reports on the effects of these herbs. ${ }^{6-8}$ The DDAC is a complex of Ardisia silvestris, Hedychium coronarium, Maesa perlarius. The Ardisia silvestris in traditional medicine reduces gastric acid, reducing pain in peptic ulcers. ${ }^{7}$ Hedychium coronarium has been reported to reduce pain, anti - inflammatory, antibiotic. ${ }^{9,10}$ According to traditional experience, Maesa perlarius has the effect of reducing pain, reducing bleeding, and quickly healing wounds. ${ }^{11}$ To have a scientific basis for the effects of DDAC for safe use, knowledge of adverse reactions, and herb drug interactions are necessary. The safety of a combination of herbal medicine in DDAC has 
not been evaluated, and as a basis for clinical trial study, we conducted: Assessment of acute toxicity and sub - chronic toxicity of DDAC in experimental animals.

\section{METHODS}

\section{Plant materials}

DDAC product was prepared in tablets form includes the ingredients: Extract of Ardisia silvestris $300 \mathrm{~g}$, extract of Hedychium coronarium $250 \mathrm{~g}$, extract of Maesa perlarius $250 \mathrm{~g}$, and other synthetic ingredients just enough for one tablet. DDAC product belongs to An Chau Pharmaceutical Joint Stock Company. This product is manufactured by Phuong Dong Pharmaceutical and Trading Company.

\section{Animals}

Acute toxicity experiment: Swiss mice (18 - $22 \mathrm{~g}$ ) of either sex were purchased from the National Institute of Hygiene and Epidemiology. Mice were reared in a laboratory of the Department of Pharmacology, Hanoi Medical University, for 7 - 10 days before the experiments with a standard food for mice (provided by the National Institute of Hygiene and Epidemiology); water was allowed ad libitum.

Sub - chronic toxicity experiment: Wistar rats $(180 \pm 20 \mathrm{~g}$ ) of either sex were purchased from Center provides laboratory animals, Dan Phuong district, Hanoi. Rats were reared in a laboratory of the Department of Pharmacology for 5 - 7 days before the experiments with standard food pellet diet for rats, and water was allowed ad libitum.

\section{Methods}

Acute toxicity experiment was carried out according to World Health Organization Guidance and determined $L_{50}$ by Litchfield Wilcoxon method ${ }^{12,13}$. The mice were fasted for
18 hours before the experiment and randomly divided into different groups, each with ten mice. DDAC was given orally in increasing doses to determine the lowest dose causing death in $100 \%$ of the mice, and the highest does not cause death in mice $(0 \%$ of death in mice). Assess the general health condition of mice and signs of toxicity such as vomiting, convulsions, agitation, abnormal excretion ... and the number of rats that died within 72 hours after giving DDAC. All dead mice were operated on to assess macroscopic lesions. The lethal dose in $50 \%\left(L_{50}\right)$ was determined by the Litchfield - Wilcoxon method. Then continue to monitor the mice for seven days after giving DDAC.

Subchronic toxicity experiment was carried out in compliance with the guidance of the World Health Organization and OECD guideline No.40712,14. Rats were randomly divided into three groups, each group of 10 rats. The DDAC was given orally for 28 consecutive days. Group 1 was kept as control and received normal clean drinking water ad libitum. Group 2 and 3 were treated with $0.58 \mathrm{~g} / \mathrm{kg} /$ day (low dose - equivalent to clinical dose) and $1.74 \mathrm{~g} /$ $\mathrm{kg} /$ day (high dose - 3 times - equivalent to clinical dose) of DDAC. Experimental animal blood samples were collected for hematology and biochemistry analysis. At the end of the experiment, rats were operated on to observe all organs' macroscopic; the histology samples (liver, kidney) were collected in $30 \%$ of rats to assess microscopic morphology.

\section{Statistical analysis}

Data sets were entered, edited and analyzed using Excel 2013 software. Results were expressed as the Mean value \pm Standard Deviation (SD) or the percentage (\%). Appropriate statistical analysis was applied with 
$p<0.05$, considered as a significant difference.

\section{RESULTS}

\section{Acute toxicity experiment}

After 72 hours of taking the DDAC, there were no mice died during the follow - up in the control group and DDAC groups. So, it was not calculated $\mathrm{LD}_{50}$ of the DDAC. Also, animals did not show any signs of acute toxicity such as piloerection, lacrimation, locomotion, respiration, and digestive changes. The number of dead mice and the dose of DDAC was showed in Table 1.

Table 1. Acute toxicity of DDAC

\begin{tabular}{lcccc}
\hline Groups & $\begin{array}{c}\text { Dosage } \\
(\mathbf{m l} / \mathbf{k g ~ b . w )}\end{array}$ & $\begin{array}{c}\text { Dosage } \\
(\mathbf{g} / \mathbf{k g ~ b . w})\end{array}$ & $\begin{array}{c}\text { Mortarity } \\
\text { rates (\%) }\end{array}$ & $\begin{array}{c}\text { Other abnormal } \\
\text { signs }\end{array}$ \\
\hline 1 & 0 & 0 & 0 & 0 \\
\hline 2 & 30 & 10.29 & 0 & 0 \\
\hline 3 & 45 & 15.43 & 0 & 0 \\
\hline 4 & 60 & 20.57 & 0 & 0 \\
\hline 5 & 75 & 25.71 & 0 & 0
\end{tabular}

\section{Sub - chronic toxicity experiments}

General condition: During the experiment period, rats in all groups had normal activities, good eating, agility, bright eyes, and dry stools.

The body weight: After two weeks and four weeks of the experiment, the body weight of rats in all groups (control group and two treatment groups) increased compared to before the experiment with statistical significance $(p<0.001, p<0.01)$. There was no difference in rats' weight gain between the control and treatment groups $(p>0.05)$. The rats' body weight was evaluated shown in the Figure 1.

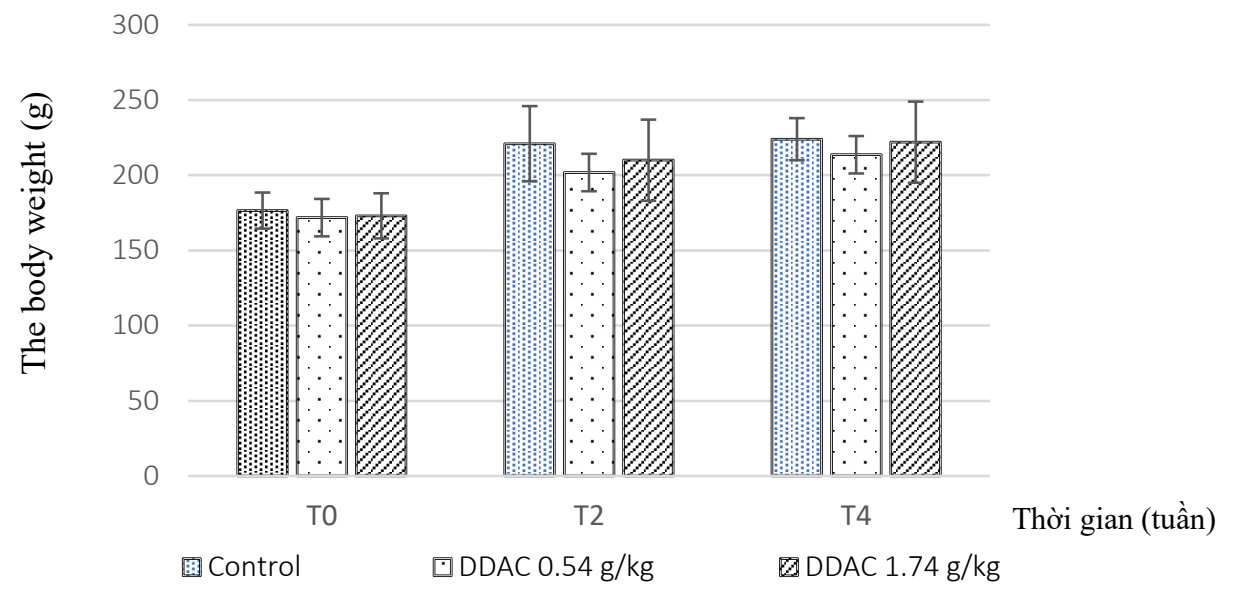

Figure 1. Effect of DDAC on rat's body weight. Data are expressed as Mean \pm SD $(n=10)$ Hematological parameters: The blood count in both group 1 (DDAC at the dose of $0.58 \mathrm{~g} / \mathrm{kg} / \mathrm{day}$ ) 


\section{JOURNAL OF MEDICAL RESEARCH}

and group 2 (DDAC at the dose of $1.74 \mathrm{~g} / \mathrm{kg} /$ day) had no significant difference from the control group, and there was no significantly different comparison between the time before and after the experiment $(p>0.05)$. Main hematological parameters of experimental animals were presented in Table 2.

Table 2. Effect of DDAC on rats hematological parameters

\begin{tabular}{|c|c|c|c|c|}
\hline Parameters & $\begin{array}{l}\text { Groups } \\
(n=10)\end{array}$ & $\begin{array}{c}\text { T0 } \\
(\bar{X} \pm \mathrm{SD})\end{array}$ & $\begin{array}{c}\text { T2 } \\
(\bar{X} \pm \mathrm{SD})\end{array}$ & $\begin{array}{c}\text { T4 } \\
(\bar{X} \pm \mathrm{SD})\end{array}$ \\
\hline \multirow{3}{*}{$\begin{array}{l}\text { Red blood cells } \\
(\mathrm{T} / \mathrm{l})\end{array}$} & Control & $8.46 \pm 0.57$ & $8.58 \pm 1.20$ & $8.63 \pm 0.51$ \\
\hline & DDAC $0.58 \mathrm{~g} / \mathrm{kg}$ & $8.65 \pm 0.81$ & $9.02 \pm 1.03$ & $8.83 \pm 0.75$ \\
\hline & DDAC $1.74 \mathrm{~g} / \mathrm{kg}$ & $8.71 \pm 1.14$ & $8.87 \pm 1.14$ & $8.91 \pm 1.07$ \\
\hline$p t-s$ & $>0.05$ & $>0.05$ & $>0.05$ & $>0.05$ \\
\hline $\mathrm{p}(\mathrm{t}$ - test student $)$ & & $>0.05$ & $>0.05$ & $>0.05$ \\
\hline \multirow{3}{*}{$\begin{array}{l}\text { Hemoglobin } \\
(\mathrm{g} / \mathrm{dl})\end{array}$} & Control & $11.87 \pm 0.74$ & $11.59 \pm 0.73$ & $11.19 \pm 1.56$ \\
\hline & DDAC $0.58 \mathrm{~g} / \mathrm{kg}$ & $11.89 \pm 1.62$ & $12.33 \pm 1.03$ & $12.15 \pm 0.52$ \\
\hline & DDAC $1.74 \mathrm{~g} / \mathrm{kg}$ & $12.27 \pm 1.47$ & $12.15 \pm 0.52$ & $12.16 \pm 1.69$ \\
\hline$p t-s$ & $>0.05$ & $>0.05$ & $>0.05$ & $>0.05$ \\
\hline $\mathrm{p}(\mathrm{t}$ - test student $)$ & & $>0.05$ & $>0.05$ & $>0.05$ \\
\hline \multirow{3}{*}{ Hematocrit (\%) } & Control & $44.80 \pm 3.51$ & $42.96 \pm 3.79$ & $43.90 \pm 3.23$ \\
\hline & DDAC $0.58 \mathrm{~g} / \mathrm{kg}$ & $43.75 \pm 6.14$ & $45.69 \pm 3.49$ & $45.96 \pm 5.15$ \\
\hline & DDAC $1.74 \mathrm{~g} / \mathrm{kg}$ & $45.73 \pm 6.65$ & $45.98 \pm 2.60$ & $45.21 \pm 6.05$ \\
\hline$p t-s$ & $>0.05$ & $>0.05$ & $>0.05$ & $>0.05$ \\
\hline $\mathrm{p}(\mathrm{t}$ - test student $)$ & & $>0.05$ & $>0.05$ & $>0.05$ \\
\hline \multirow{3}{*}{$\operatorname{MCV}(\mathrm{fl})$} & Control & $51.90 \pm 3.28$ & $50.90 \pm 2.73$ & $51.30 \pm 3.13$ \\
\hline & DDAC $0.58 \mathrm{~g} / \mathrm{kg}$ & $52.09 \pm 1.92$ & $51.00 \pm 2.79$ & $50.64 \pm 1.57$ \\
\hline & DDAC $1.74 \mathrm{~g} / \mathrm{kg}$ & $52.40 \pm 3.06$ & $51.30 \pm 2.31$ & $50.80 \pm 2.44$ \\
\hline$p t-s$ & $>0.05$ & $>0.05$ & $>0.05$ & $>0.05$ \\
\hline $\mathrm{p}(\mathrm{t}$ - test student) & & $>0.05$ & $>0.05$ & $>0.05$ \\
\hline \multirow{3}{*}{$\begin{array}{l}\text { White blood cells } \\
(G / l)\end{array}$} & Control & $9.66 \pm 1.49$ & $10.02 \pm 1.72$ & $10.19 \pm 2.14$ \\
\hline & DDAC $0.58 \mathrm{~g} / \mathrm{kg}$ & $9.21 \pm 1.96$ & $10.49 \pm 2.42$ & $9.85 \pm 2.72$ \\
\hline & DDAC $1.74 \mathrm{~g} / \mathrm{kg}$ & $10.43 \pm 1.57$ & $10.00 \pm 1.72$ & $10.77 \pm 2.77$ \\
\hline$p t-s$ & $>0.05$ & $>0.05$ & $>0.05$ & $>0.05$ \\
\hline $\mathrm{p}(\mathrm{t}$ - test student $)$ & & $>0.05$ & $>0.05$ & $>0.05$ \\
\hline
\end{tabular}




\begin{tabular}{llccc}
\hline Parameters & $\begin{array}{l}\text { Groups } \\
(\mathbf{n}=\mathbf{1 0})\end{array}$ & $\begin{array}{c}\text { T0 } \\
(\overline{\boldsymbol{X}} \pm \mathbf{S D})\end{array}$ & $\begin{array}{c}\text { T2 } \\
(\bar{X} \pm \mathbf{S D})\end{array}$ & $\begin{array}{c}\text { T4 } \\
(\bar{X} \pm \text { SD })\end{array}$ \\
\hline Platelet $(\mathrm{G} / \mathrm{l})$ & Control & $679.80 \pm 116.27$ & $705.10 \pm 78.06$ & $723.50 \pm 101.97$ \\
\hline & DDAC $0.58 \mathrm{~g} / \mathrm{kg}$ & $720.09 \pm 130.70$ & $698.91 \pm 110.99$ & $705.45 \pm 146.35$ \\
\hline $\mathrm{pt}-\mathrm{s}$ & DDAC $1.74 \mathrm{~g} / \mathrm{kg}$ & $642.80 \pm 109.50$ & $597.20 \pm 120.30$ & $701.40 \pm 135.19$ \\
\hline $\mathrm{p}(\mathrm{t}-$ test student $)$ & & $>0.05$ & $>0.05$ & $>0.05$ \\
\hline
\end{tabular}

The liver functions: The effects of sub - chronic administration DDAC to rats on serum biochemical parameters at the termination of treatment are shown in Tables 3. The serum biochemical indices results indicate that DDAC tablets did not cause significant differences $(p>0.05)$ in the liver functions between groups - treated and control groups. There was no significant difference comparing the before and after treatment ( $p>0.05)$.

Table 3. Effect of DDAC on rat's plasma biochemical parameters for liver function

\begin{tabular}{|c|c|c|c|c|}
\hline Parameters & $\begin{array}{l}\text { Groups } \\
(n=10)\end{array}$ & $\begin{array}{c}\text { TO } \\
(\bar{X} \pm \text { SD })\end{array}$ & $\begin{array}{c}\text { T2 } \\
(\bar{X} \pm \mathrm{SD})\end{array}$ & $\begin{array}{c}\text { T4 } \\
(\bar{X} \pm \mathrm{SD})\end{array}$ \\
\hline \multirow{3}{*}{ Total Albumin (g/dL) } & Control & $3.22 \pm 0.18$ & $3.08 \pm 0.35$ & $3.03 \pm 0.22$ \\
\hline & DDAC $0.58 \mathrm{~g} / \mathrm{kg}$ & $3.16 \pm 0.38$ & $3.04 \pm 0.32$ & $3.12 \pm 0.36$ \\
\hline & DDAC $1.74 \mathrm{~g} / \mathrm{kg}$ & $3.23 \pm 0.29$ & $3.14 \pm 0.39$ & $3.12 \pm 0.27$ \\
\hline$p t-s$ & $>0.05$ & $>0.05$ & $>0.05$ & $>0.05$ \\
\hline $\mathrm{p}(\mathrm{t}$ - test student) & & $>0.05$ & $>0.05$ & $>0.05$ \\
\hline \multirow{3}{*}{ Total Cholesterol (mmol/L) } & Control & $1.72 \pm 0.27$ & $1.85 \pm 0.28$ & $1.67 \pm 0.35$ \\
\hline & DDAC $0.58 \mathrm{~g} / \mathrm{kg}$ & $1.75 \pm 0.33$ & $1.66 \pm 0.27$ & $1.56 \pm 0.27$ \\
\hline & DDAC $1.74 \mathrm{~g} / \mathrm{kg}$ & $1.71 \pm 0.36$ & $1.76 \pm 0.16$ & $1.82 \pm 0.46$ \\
\hline$p t-s$ & $>0.05$ & $>0.05$ & $>0.05$ & $>0.05$ \\
\hline $\mathrm{p}(\mathrm{t}$ - test student $)$ & & $>0.05$ & $>0.05$ & $>0.05$ \\
\hline \multirow{3}{*}{ Total bilirubin (mmol/L) } & Control & $13.36 \pm 0.25$ & $13.49 \pm 0.28$ & $13.50 \pm 0.47$ \\
\hline & DDAC $0.58 \mathrm{~g} / \mathrm{kg}$ & $13.45 \pm 0.32$ & $13.40 \pm 0.25$ & $13.31 \pm 0.30$ \\
\hline & DDAC $1.74 \mathrm{~g} / \mathrm{kg}$ & $13.35 \pm 0.28$ & $13.47 \pm 0.26$ & $13.37 \pm 0.42$ \\
\hline$p t-s$ & $>0.05$ & $>0.05$ & $>0.05$ & $>0.05$ \\
\hline $\mathrm{p}(\mathrm{t}$ - test student $)$ & & $>0.05$ & $>0.05$ & $>0.05$ \\
\hline
\end{tabular}

The levels of liver cell distruction: The tests' results to assess the level of liver cell destruction (AST, ALT activities in rat blood) were shown in Figure 2. Both treatment group 1 and treatment group 2 did not significantly differ from the control group and compared between two times before and after taking DDAC $(p>0.05)$. 

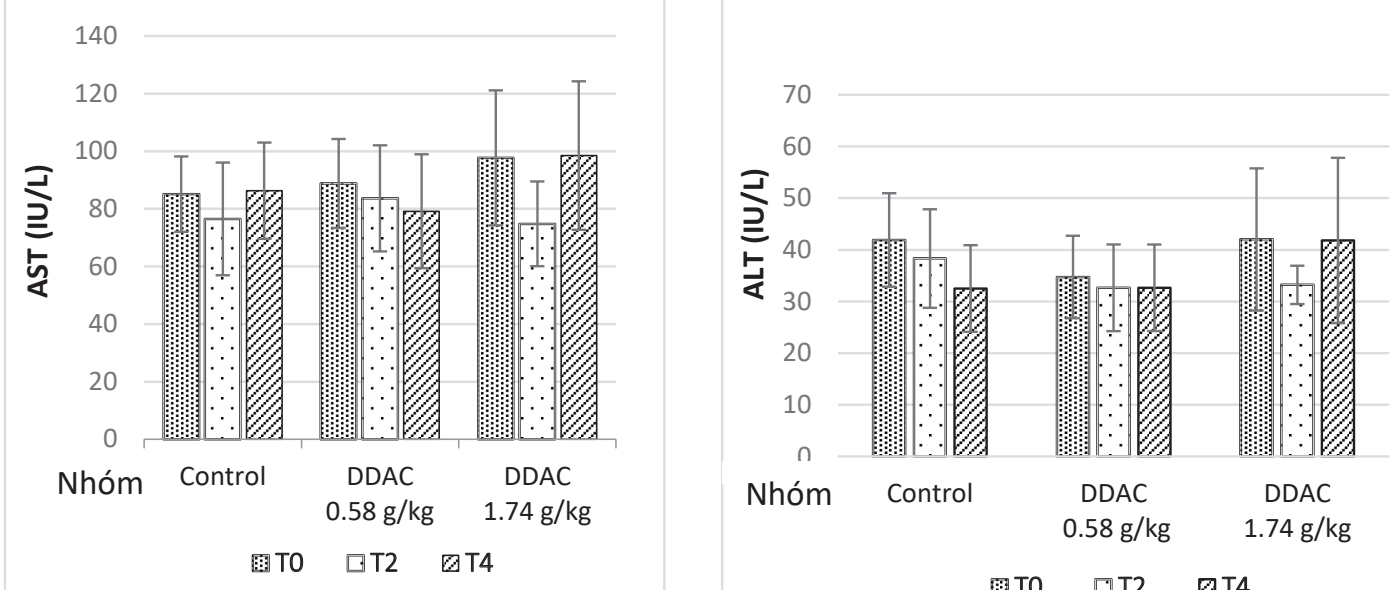

Figure 2. Effects of DDAC on rat's plasma biochemical parameters for level of liver cells destruction. Data are expressed as Mean \pm SD $(n=10)$.

Kidney functions: There were no significant differences in the concentration of serum markers of kidney functions than the control group. The results were shown in Table 4

Table 4. Effect of DDAC on rats plasma biochemical parameters for kidney function

\begin{tabular}{llccc}
\hline \multicolumn{1}{c}{ Parameter } & \multicolumn{1}{c}{$\begin{array}{c}\text { Groups } \\
(\mathbf{n}=\mathbf{1 0})\end{array}$} & $\begin{array}{c}\text { T0 } \\
(\bar{X} \pm \mathbf{S D})\end{array}$ & $\begin{array}{c}\text { T2 } \\
(\overline{\boldsymbol{X}} \pm \mathbf{S D})\end{array}$ & $\begin{array}{c}\text { T4 } \\
(\bar{X} \pm \mathbf{S D})\end{array}$ \\
\hline \multirow{3}{*}{ Creatinine $(\mathrm{mg} / \mathrm{dL})$} & Control & $0.80 \pm 0.13$ & $0.80 \pm 0.15$ & $0.78 \pm 0.14$ \\
\cline { 2 - 5 } & DDAC $0.58 \mathrm{~g} / \mathrm{kg}$ & $0.84 \pm 0.15$ & $0.81 \pm 0.13$ & $0.78 \pm 0.17$ \\
\cline { 2 - 5 } $\mathrm{pt}-\mathrm{s}$ & DDAC $1.74 \mathrm{~g} / \mathrm{kg}$ & $0.82 \pm 0.12$ & $0.91 \pm 0.17$ & $0.81 \pm 0.18$ \\
\hline $\mathrm{p}$ (t - test student) & $>0.05$ & $>0.05$ & $>0.05$ & $>0.05$ \\
\hline
\end{tabular}

Effect of DDAC on experimental animal histopathology: In all experiment rats (control group and DDAC treated - groups), no pathological changes in all organs' macroscopic were observed: heart, lung, liver, spleen, pancreas, kidney and digestive system. The effects on the liver and kidney histopathology after treatment are shown in Figure 3 - 4. Results showed that DDAC did not affect the morphology of the kidney and liver in experimental animals.

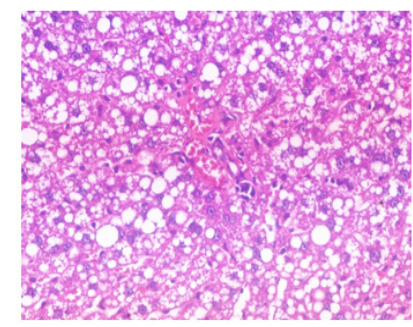

a. Control group (40x, HE)

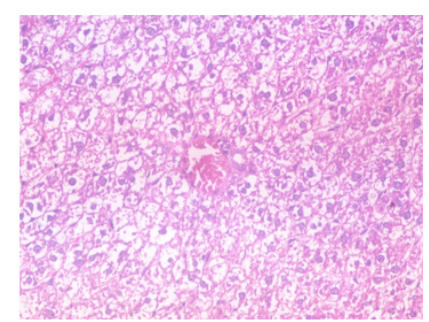

b. DDAC $0.58 \mathrm{~g} / \mathrm{kg}(40 \mathrm{x}, \mathrm{HE})$

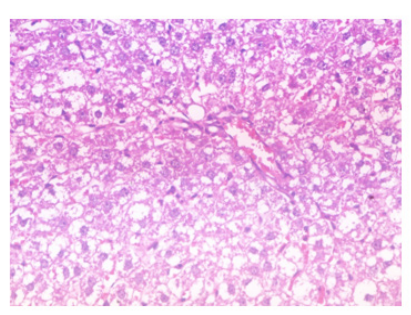

c. DDAC $1.74 \mathrm{~g} / \mathrm{kg}(40 \mathrm{x}, \mathrm{HE})$

Figure 3. Liver sections of control rats (a) and rats treated daily with DDAC at two doses of $0.58 \mathrm{~g} / \mathrm{kg}$ (b), $1.74 \mathrm{~g} / \mathrm{kg}$ (c) 


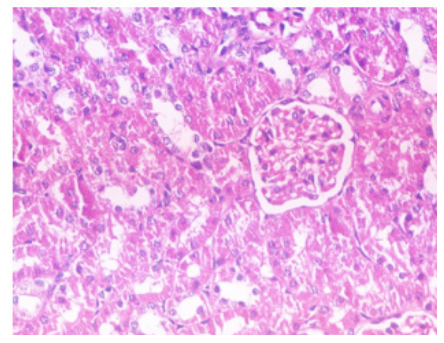

a. Control group (40x, HE)

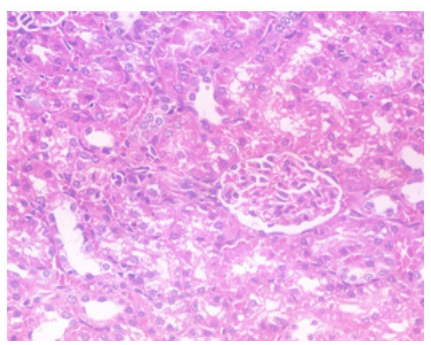

b. DDAC $0.58 \mathrm{~g} / \mathrm{kg}(40 \mathrm{x}, \mathrm{HE})$

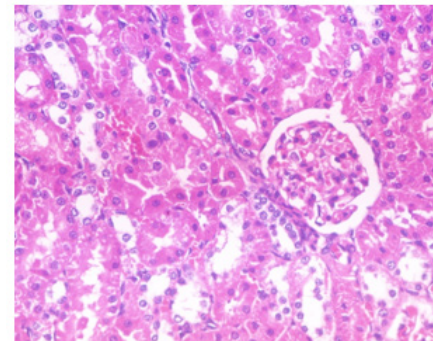

c. DDAC $1.74 \mathrm{~g} / \mathrm{kg}(40 \mathrm{x}, \mathrm{HE})$

Figure 4. Kidney sections of control rats (a) and rats treated daily with DDAC at two doses of $0.58 \mathrm{~g} / \mathrm{kg}(\mathrm{b}), 1.74 \mathrm{~g} / \mathrm{kg}(\mathrm{c})$.

\section{DISCUSSION}

In Vietnam, there is increasing interest in treating with herbal medicine. However, information about the toxicities of these herbs is limited. Toxicity research is an essential step in the development of a traditional medicine recipe. If a remedy wants to be used for treatment and its effective effects, it is necessary to ensure safety. So the toxicity assessment helps provide a piece of scientific evidence for the safe when a combination of medicinal herbs in the remedy.

In acute toxicity experiment: At a maximum dose equivalent to $25.71 \mathrm{~g} / \mathrm{kg}$ (the highest possible dose given to rats) 38 times the usual clinical dose did not cause symptoms of acute toxicity in mice, there was no animal died after 48 hours, and 72 hours, and after seven days of taking DDAC, there were no abnormal signs. Therefore, the $L_{50}$ of the test product could not be determined in mice. According to Do Tat Loi, Ardisia silvestris at high doses only causes a decrease in mice activity, at the dose of $250 \mathrm{~g}$ of medicinal herbs per day used clinically causes drowsiness, pale skin, and declining health if long - term use. ${ }^{6}$ Dose Ardisia silvestris of in DDAC is $1.8 \mathrm{~g}$ of medicinal herbs per day, much lower than the dose showing toxicity in clinical. Further, the study of Nguyen Thi Kim Thuy et al. (2013) showed that Coronarin E compound, one of the main components extracted from the stems and roots of Hedychium coronarium (1 gram of stem, roots powder of Hedychium coronarium can extract $100 \mathrm{mg}$ of Coronarin E). The $L D_{50}$ of Coronarin $E$ was also determined at a dose of $7000 \mathrm{mg} / \mathrm{kg}$. The maximum Coronarin $\mathrm{E}$ dose in DDAC used in this study (approximately $642.75 \mathrm{mg} / \mathrm{kg}$ for acute toxicity) is much lower than the study of Nguyen Thi Kim Thuy et al. ${ }^{15}$

In the subchronic toxicity experiment: Rats were given "Da day An Chau" for four consecutive weeks; the general condition reflects the health status of the animal. At clinically equivalent dose and dose three times rats' general condition, the clinical dose of DDAC did not affect rats' general condition when taking for four consecutive weeks. The body weight change is an essential index for the assessment of toxicity. Substances that are toxic to the organs can lead to excessive changes in the weight of experimental animals. Figure 1 demonstrates that "Da day An Chau" tablets at both doses do not affect the rats' normal weight development.

The blood cells are produced in the bone marrow. The blood is affected by all of organs and it also affects and reflects the specific state of the hematopoietic system. The results from Table 2 showed that: there was not charge in the 
hematological parameters between treatment groups and control group at the same time as study. Hence, DDAC may not have deleterious effects on bone marrow function.

The liver is responsible for many complex functions and is the main metabolizing organ of drugs, the main role in synthesis and metabolism of substances in the body such as protein, lipid, bile ... When a drug is introduced into the body, drugs can toxic to the liver, cause damage to liver cells, affect liver function. Therefore, to assess the level of destruction and function of liver cells that often quantify the activity of enzymes or substances in the plasma such as AST, ALT, bilirubin, albumin, cholesterol. The kidney is the secretory organ of the body. Most of the drug is excreted by the kidneys. The creatinine concentration in the blood is used to evaluate glomerular filtration capability. Research results show that DDAC does not change the indicators (AST, ALT, bilirubin, albumin, cholesterol, creatinine ) in all rats' plasma. There was no difference in the microscopic liver and kidney compared to the control group. Thus, both doses of DDAC do not affect the liver, kidney functions, and histopathology of liver, kidney structure.

Currently, there is limited research on the toxicity of the medicinal herbs in DDAC. According to a study by Nguyen Thi Kim Thuy et al. (2013), Coronarin E compound extracted from the stems and roots of Hedychium coronarium at a dose of $100 \mathrm{mg} / \mathrm{kg} /$ day and 500 $\mathrm{mg} / \mathrm{kg} /$ day causes a decrease in the number of red blood cells, hemoglobin and trends to affect the level of liver cell destruction, kidney function (assessed through the indexes: Creatinine, AST, ALT). The maximum Coronarin $E$ dose in DDAC used in the sub - chronic toxicity study (approximately $43.5 \mathrm{mg} / \mathrm{kg}$ ) is much lower than the above study. ${ }^{15}$ In the remaining, there have been no reports of sub - chronic toxicity of other herbs in DDAC.

\section{CONCLUSION}

Mice were given a maximum dose of 25.71 $\mathrm{g} / \mathrm{kg}$ with no acute oral toxicity manifestations, LD50 of DDAC has not been determined.

DDAC with a dose equivalent to the clinical dose and three times the clinical dose did not cause sub - chronic oral toxicity after four weeks of study.

\section{REFERENCES}

1. Vu Van Khien. Study the effectiveness of treatment of esomeprazole (Nexium) in patients with gastroesophageal reflux disease. Vietnam Journal of Medicine and Pharmacy. 2008; 342(1): 37-40.

2. Duong Hong Thai, Dong Duc Hoang. Evaluate the value of the GERDQ questionnaire in detecting the demand for treating gastroesophageal reflux disease. Thai Nguyen University of Science and Technology Journal. 2012; 89: 49-53.

3. A. Becher, H. El - Serag. Systematic review: The association between symptomatic response to proton pump inhibitors and health - related quality of life in patients with gastro - oesophageal reflux disease. Alimentary Pharmacology \& Therapeutics. 2011; 34(6): 618-627.

4. Koji Takeuchi, Kenji Nagahama. Animal Model of Acid - Reflux Esophagitis: Pathogenic Roles of Acid/Pepsin, Prostaglandins, and Amino Acids. BioMed Research International. 2014; Volume 2014: 1-10.

5. Ministry ofhealth. VietnamPharmacopoeia. Medical Publishing House. 2018; 1243-1244.

6. Do Tat Loi. Vietnamese medicinal plants and herbs. In: Hong Duc Publishing House; 2005:481 - 482.

7. Huynh Tan Hoi. H. Pylori bacteria - cause 
of peptic ulcer and some treatments. Journal of Critical Reviews. 2020;7(14):887 - 890.

8. Do Huy Bich et al. Medicinal plants and medicinal animals in Vietnam. Hanoi Science and Technology Publishing House. 2006; 141143.

9. Aziz M. A, Habib M. R, Karim M. R. Antibacterial and Cytotoxic Activities of Hedychium coronarium J. Koenig. Research Journal of Agriculture and Biological Sciences. 2009; 5(6): 969-972.

10. Suresh G, Reddy P. P, Babu K. S. Two new cytotoxic labdane diterpenes from the rhizomes of Hedychium coronarium. Bioorganic \& amp; Medicinal Chemistry Letters. 2010; 20: $7544-7548$.

11. Hua Hongping. An article for the treatment of psoriasis according to traditional Chinese medicine. Licensed by the State Intellectual Property office of the People's Republic of
China. 2015.

12. WHO. Working group on the safety and efficacy of herbal medicine", Report of regional office for the western pacific of the World Health Organization. 2000.

13. Litchfield. J. T, Wilcoxon. F. A simplified method of evaluating dose - effect experiments. Journal of Pharmacology and Experimental Therapeutics. 1949;96:99 - 113.

14. OECD. Test Guideline for the Testing of Chemicals. Repeated dose 28 - day Oral toxicity Study in Rodents, OECD 407. 2008.

15. Nguyen Thi Kim Thuy. Research on the chemical composition and biological activity of substances extract from Hedychium coronarium Koenig. Chemistry and natural compounds. Institute of Natural Products Chemistry Vietnam Academy of Science and Technology. 2013. 